\title{
Tubulin Binding Agent
}

National Cancer Institute

\section{Source}

National Cancer Institute. Tubulin Binding Agent. NCI Thesaurus. Code C25974.

Any agent that binds to tubulin molecules and interferes with the microtubule assembly and disassembly dynamic. A tubulin binding agent impedes cell division and can be used to treat a variety of cancers. 